\title{
Experimental study of the impact response of geocells as components of rockfall protection embankments
}

\author{
S. Lambert ${ }^{1,3}$, P. Gotteland ${ }^{2,3}$, and F. Nicot ${ }^{1,3}$ \\ ${ }^{1}$ Cemagref, UR ETGR, 38402 St-Martin d'Hères, France \\ ${ }^{2} 3$ SR, UMR5521, DU Grenoble Universités, 38041 cedex 9, Grenoble, France \\ ${ }^{3}$ VOR-RNVO Group: Research Network on Natural Hazards and Vulnerability of Structures, France
}

Received: 6 January 2009 - Revised: 18 March 2009 - Accepted: 18 March 2009 - Published: 30 March 2009

\begin{abstract}
Rockfall protection embankments are ground levees designed to stop falling boulders. This paper investigates the behaviour of geocells to be used as components of these structures. Geocells, or cellular confinement systems, are composite structures associating a manufactured envelope with a granular geomaterial. Single cubic geocells were subjected to the impact resulting from dropping a spherical boulder. The geocells were filled with fine or coarse materials and different boundary conditions were applied on the lateral faces. The response is analysed in terms of the impact force and the force transmitted by the geocell to its rigid base. The influence on the geocell response of both the fill material and the cell boundary conditions is analysed. The aim was to identify the conditions resulting in greatest reduction of the transmitted force and also to provide data for the validation of a specific numerical model.
\end{abstract}

\section{Introduction}

Rockfalls are a major threat in mountainous regions for roads, railways, buildings and inhabitants. Even low-energy events, which are very frequent, can have tragic consequences. Infrastructures at risk can be protected against falling boulders with civil engineering structures placed down the slope to stop or deviate the boulder: shelters, metallic net fences or embankments. The choice between these different passive interventions is mainly based on the site topography and the energy of the falling boulder. For example, embankments are effective when boulders have a translational kinetic energy higher than 5MJ (Descoeudres, 1997),

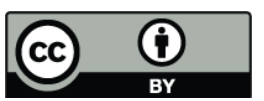

Correspondence to: S. Lambert (stephane.lambert@cemagref.fr) whereas galleries are appropriate for road protection at the toe of vertical cliffs.

Embankments are ground structures most often reinforced with horizontal inclusions such as geotextiles or geogrids. Reinforcement inclusions are used to steepen the embankment slope exposed to impacts so as to prevent boulders from get over the structure. Their efficiency in stopping falling boulders mainly depends on their mass. These structures are massive, with height varying from 3 up to $20 \mathrm{~m}$. and length up to more than a few hundred meters. As a consequence, setting up such structures requires large areas, a problem on mountainous sites.

The design of rockfall protection embankments requires knowing the mass of the boulder to be stopped, its velocity and its maximal height of flight in the projected building area. The first design requirement is stability versus gravity. It is sometimes the only component considered. Indeed, designing embankments that fully take into account the mechanisms at work during the impact is very complex because the impact by a high-kinetic-energy boulder induces large and irreversible deformations in the embankment. A number of analytical methods have been developed but remain relatively approximate. For instance, Tissières (1999) compared the boulder braking force to the embankment shearing force assuming that during the impact a section of the embankment is displaced as a rigid body. Generally speaking engineers design the structure by modelling the impact force by an equivalent static surcharge (Jaecklin, 2006). Numerical simulations, based on the finite element method or the discrete element method, appear to be more appropriate and satisfactory in attempting to account for the complexity of the impact on embankments (Burroughs et al., 1993; Hearn et al., 1995; Peila et al., 2002, 2007; Plassiard et al., 2004; Carotti et al., 2004; Sung et al., 2007). Indeed, even

Published by Copernicus Publications on behalf of the European Geosciences Union. 


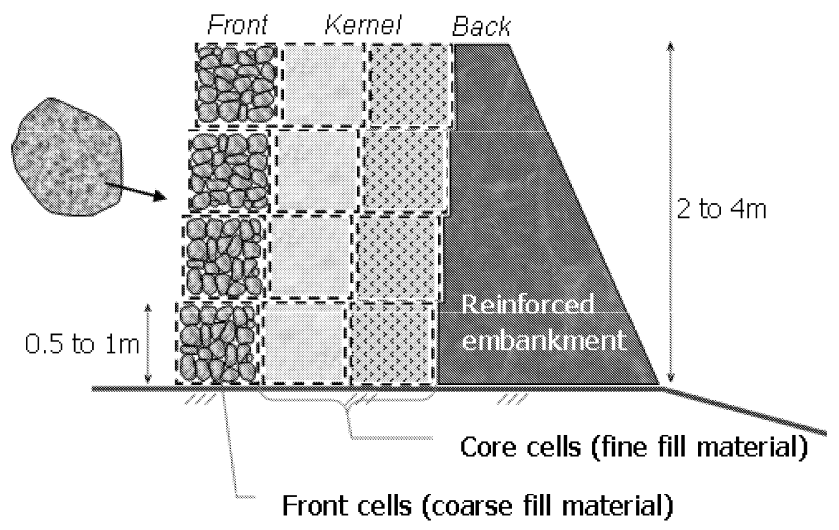

Fig. 1. Illustration of the principle of a cellular rockfall protection embankment.

if complex, these approaches obtain fair agreement with the few available real-scale experimental data bases (Burroughs et al., 1993; Peila et al., 2002; Sung et al., 2007). Nevertheless, the design of embankments generally does not account for the dynamic response of the structure satisfactorily.

Therefore a thorough study of these structures is still needed. Some authors have investigated the behaviour of granular geomaterials through real-scale impact experiments on in-situ soil layers (Pichler et al., 2005), damping material laid on rigid bases (Labiouse et al., 1994; Montani Stoffel, 1998; Calvetti et al., 2005; Schellenberg et al., 2008) as well as on embankments (Burroughs et al., 1993; Peila et al., 2002). Model tests on layers of damping materials (Chikatamarla, 2005; Lorentz et al., 2006) and embankments (Lepert and Corté, 1988; Blovsky, 2002) were also performed. It is nevertheless difficult to extrapolate these results to other types of structures and materials since both the mechanical characteristics and thickness of the impacted material as well as the boundary conditions strongly influence the system's response (Montani Stoffel, 1998; Calvetti, 1998).

Geocells are composite structures combining an envelope with a granular fill material. The manufactured products used as envelopes are mainly geotextiles, high density polyethylene (HDPE) sheets or metallic meshes. Different forms of geocells are employed in geotechnical applications: base reinforcement of roads (Yuu et al., 2008), flexible gravity walls (Chen and Chiu, 2008), and sea coast and river bank erosion control.

As for rockfall protection embankments, geocells can be used to build sandwich protection structures. Indeed, by changing the fill material it is possible to adapt the mechanical characteristics of the geocell depending on its position in the structure, similarly to what was proposed by Yoshida (1999). Figure 1 illustrates this principle for gabion cages filled with fine and coarse materials. The aim of this type of structure is to concentrate strains within both the front and kernel parts, whereas low strains occur in the back part
(Fig. 1). This should reduce the width of the structure for a given boulder's kinetic energy.

Compared with more classical soil-reinforced rockfall protection embankments, the main difference is that deformations and degradations are accepted during the impact. The kinetic energy of the boulder is dissipated in the front and core-cells, with limited influence on the back of the structure. In case of a low-energy event, only the front-face geocells will be deformed. Higher energy impacts will result in front-face geocell degradation and, possibly, core-cell deformation. The cellular nature of the structure facilitates maintenance work consisting in mesh repair or replacement of damaged geocells.

The use of geocells thus offers an alternative for the construction of rockfall protection embankments, at least for energy events up to $10 \mathrm{MJ}$ (RiskYdrogéo, 2006). Moreover, the same principle can be applied to enhance the impact resistance of existing embankments.

This study considers gabion cages with either fine or coarse granular noncohesive fill materials.

Many authors have studied cellular structures used for various applications and subjected to static loadings (Reiffsteck, 1998; Racana et al., 2002; Madhavi Latha et al., 2006; Dash et al., 2007; Wesseloo et al., 2009). Scherbatiuk et al. (2008) studied the stability of cellular structures subjected to dynamic loadings caused by blast. At the cell scale, the confinement effect of an envelope on a granular geomaterial has mainly been studied under static loadings (Bathurst and Rajagopal, 1993; Gourvès et al., 1996; Rajagopal et al., 1999; Iizuka et al., 2004). In these studies, cells were mainly filled with fine materials and had a cross-section like either a circle or honeycomb. Agostini et al. (1987) presented data on the compression response of geocells made up of wire netting cages filled with coarse materials. To our knowledge the response of cube-like geocells, filled either with fine or coarse granular materials and subjected to loadings similar to those resulting from the impact by a boulder has never been investigated.

To develop the use of cellular technology in rockfall protection embankment, an intensive study (the REMPARe project, http://www.rempare.fr) was initated, combining experiments with numerical modelling following a multi-scale approach, from the constitutive material to the structure scale. The aim of the REMPARe project is to provide operational solutions for the design of such earthworks for small to medium rock fall energies that includes the use of recycled waste products such as used tyres. In this frame, the geocell response was investigated under static loading before the impact response of the geocells was studied.

The aim of this paper is to present and discuss the experimental results obtained on the response of single cubic geocells impacted by a boulder. The main parameters of concern are the geocell fill material and the geocell boundary conditions. The objective of the study was to identify the main phenomena involved during the impact and to identify the 

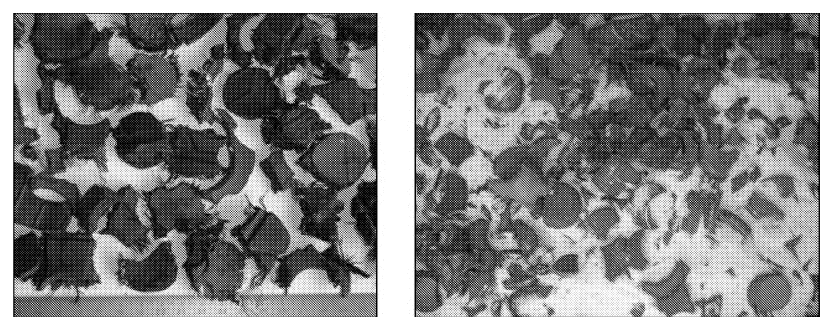

Fig. 2. Scrapped tyres and $30 \%$ by mass tyre-sand mixture.

conditions resulting in a lower transmitted force. In addition, these experiments were designed to provide data for the calibration of a numerical model of geocells filled with coarse materials and developed using the discrete element method (Bertrand et al., 2006).

\section{Materials and method}

\subsection{Cell fill materials and envelope}

The fill materials were coarse or fine granular noncohesive materials. The former were crushed quarry limestone, 60 to $180 \mathrm{~mm}$ in grain size. This material is typical for a talus slope. It is hereafter referred to as "stone". The rock Young modulus was $57700 \mathrm{MPa}$. The average crushing resistance of stones $100 \mathrm{~mm}$ in size was $30 \mathrm{kN}$. The latter consisted of Hostun sand or scrapped tyres. Hostun sand is a welldocumented and well-graded sand whose size distribution ranges from 0.08 to $1 \mathrm{~mm}$ and with a friction angle of $32.5^{\circ}$ (cohesion nil). The scrapped tyres result from the puncturing of end-of-life tyres. This material contains $30 \%$ by mass of circular pieces $25 \mathrm{~mm}$ in diameter and $10 \mathrm{~mm}$ in average thickness, the rest having no particular shape (Fig. 2). This material was considered both for waste recycling purposes and to take advantage of its particular mechanical characteristics, very different from the properties of more classical granular geomaterials.

Sand was used alone or as a mixture containing $30 \%$ by mass of tyres. This mixture constitutes a reinforced and lightweight composite material (Zornberg et al., 2004; Gotteland et al., 2005).

The envelope was made up of a hexagonal, or doubletwisted, wire mesh. The mesh height and width were $80 \mathrm{~mm}$ and $100 \mathrm{~mm}$, respectively, and the wire had a $2.7 \mathrm{~mm}$ diameter. The tensile strength of this wire mesh was $51 \mathrm{kN} / \mathrm{m}$. For fine fill materials, a containment non-woven needle punched geotextile was used in combination with the wire mesh. The geocells, or cells, considered in this study were cubic in shape, $500 \mathrm{~mm}$ in height. Gabion cages are generally parallelepiped in shape but subdivided into three cubic parts that are considered here as the elementary unit. Prior to filling, the cells were placed in a wooden box in order to prevent any lateral deformation. Stone cells, i.e. geocells filled with the
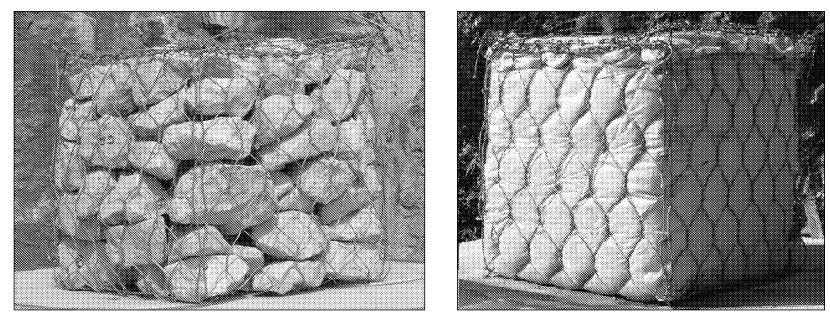

Fig. 3. Cells filled with stones and sand.

coarse material, were filled placing the stones flat. Fine materials were poured dry then slightly compacted. No internal connecting wire was placed across the cell, contrary to what is generally done on real structures. The average cell weight was 205, 203 and $195 \mathrm{~kg}$ for stones, sand and mixture cells, respectively (Fig. 3). Their precise density is not known as it was not possible to accurately determine the volume occupied by the fill material.

\subsection{Experimental methodology}

The cells were subjected to vertical impact by a $260 \mathrm{~kg}$ spherical boulder, $54 \mathrm{~cm}$ in diameter and made of a steel shell filled with concrete. A hollow cylinder allowed placing a $\pm 500 \mathrm{~g}$ tri-axial piezoelectric accelerometer close to its centre of gravity (Lambert, 2007). The filled cell was placed on a rigid pedestal made of reinforced concrete (Fig. 4). It was $0.7 \mathrm{~m}$ in height and had a $1.2 \mathrm{~m}$ side square horizontal crosssection. This deviates from the real conditions as illustrated in Fig. 1 where the surface in contact with the rear of the cell is not rigid. It deforms depending on the force transmitted by the cell, modifying in turn the cell response. Nevertheless, considering both the scale of interest (the cell) and the goals of this study a rigid support was considered.

To reproduce the possible boundary conditions prevailing at the structure scale, three different test conditions were considered. The four lateral faces of the impacted cell were (i) free to deform (ii) rigidly confined or (iii) confined by the same material as the cell fill material (Fig. 5). These test conditions will be respectively referred to as FD, RC and MC conditions. Rigid confinement was obtained using three rigid steel square frames. Despite its simplicity, it appeared to satisfactorily confine the cell. The material surrounding the cell in MC conditions was contained by a wood and steel structure $0.5 \mathrm{~m}$ in height and $1.2 \times 1.2 \mathrm{~m}$ in horizontal section (the whole surface of the pedestal was covered with this confining material and the cell). The RC and FD conditions provided asymptotic responses that can be easily compared with results obtained from numerical simulations while the MC conditions provided the most realistic boundary conditions.

The impacting boulder release system can drop the boulder from height up to $7.5 \mathrm{~m}$ with an impact centred on the cell and without boulder rotation. 


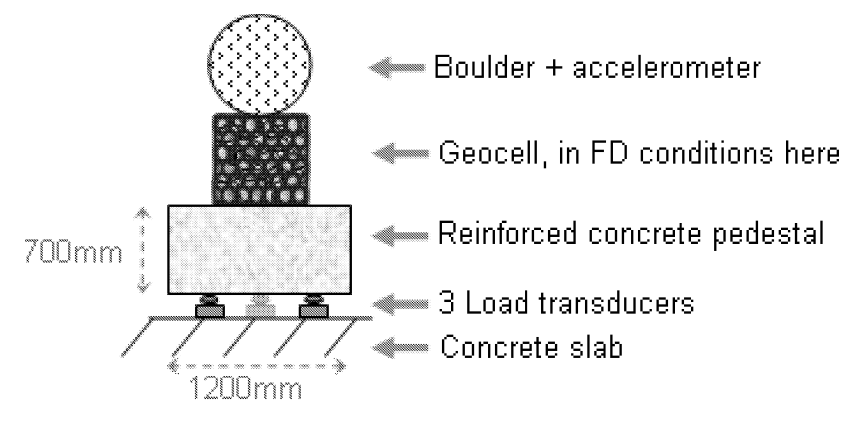

Fig. 4. Sketch of the experimental set-up.

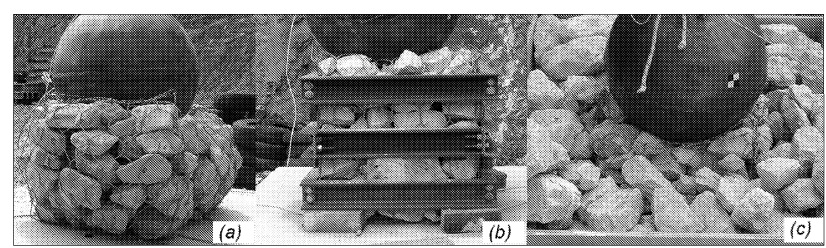

Fig. 5. Cells filled with stones in the different lateral boundary conditions, after impact: free to deform - FD (a); rigid confinement $\mathrm{RC}$ (b) and material confinement - MC (c).

The evaluation of the response of the cells is mainly based on the force applied by the boulder on the cell and the force transmitted by the cell to its pedestal. The first is the impact force, denoted $F_{\text {imp }}$, which is obtained by multiplying the deceleration of the boulder by its mass. The force transmitted by the cell to the pedestal, denoted $F_{\text {trans }}$, could not be measured directly beneath the cell because the stones were coarse. It was measured by three force transducers supporting the rigid pedestal (capacity $500 \mathrm{kN}$ each) laid on the concrete slab of the testing site (Fig. 4).

The final penetration of the boulder in the cell, $P$, was also measured as the distance covered by the boulder from the beginning of the impact to the stability position. For cells filled with fine materials, this penetration was less than the maximal penetration during the impact. The duration of the impact, $d_{\text {imp }}$, was deduced from the boulder's acceleration measurements. The restitution coefficient, $R$, was calculated as the ratio between the reflected velocity and the incident velocity.

\section{Results}

The results presented in the following concern $13.5 \mathrm{~kJ}$ impacts obtained dropping the spherical boulder from a $5.5 \mathrm{~m}$ height, giving an incident velocity of $10 \mathrm{~m} / \mathrm{s}$. The tests are listed in Table 1. The test reference indicates the fill material ("Ston", "Sand" or "Mixt" respectively for stones, sand and mixture) followed by the cell boundary conditions (FD, MC
Table 1. Main results of the impact tests.

\begin{tabular}{lccccc}
\hline $\begin{array}{l}\text { Test } \\
\text { ref. }\end{array}$ & $\begin{array}{c}F_{\text {imp }}^{\max } \\
(\mathrm{kN})\end{array}$ & $\begin{array}{c}F_{\text {trans }}^{\max } \\
(\mathrm{kN})\end{array}$ & $\begin{array}{c}d_{\mathrm{imp}} \\
(\mathrm{ms})\end{array}$ & $\begin{array}{c}R \\
(-)\end{array}$ & $\begin{array}{c}P \\
(\mathrm{~cm})\end{array}$ \\
\hline StonFD* & $128-144$ & $77-75$ & $100-110$ & - & 37 \\
StonMC $^{*}$ & 107 & $188-214$ & $36-40$ & - & 13 \\
StonRC & 242 & 377 & 26 & 0.12 & 8 \\
SandFD & 90 & 128 & 70 & 0.13 & 20 \\
SandMC* & 130 & 226 & 32 & - & 11 \\
SandRC & 346 & 601 & 22 & 0.18 & 6 \\
MixtFD* & $98-140$ & $143-157$ & 60 & 0.13 & 24 \\
MixtMC & 140 & 269 & 40 & 0.25 & 9 \\
\hline
\end{tabular}

and RC). Tests labelled with a star were performed twice. Tests in rigid confinement conditions on cells filled with the tyre-sand mixture were not performed because we feared that the rebound would be too great based on the results from other test conditions.

Table 1 gives the main results from impact tests in the various conditions. In tests performed twice, both values are presented if significantly different. The impact and transmitted forces given are the maximum values. In some cases, the restitution coefficient was low and not reliable ("--" in the table).

Figure 6 shows the impact force and transmitted force measured during impacts on sand cells and stone cells, in the different boundary conditions. Scales are different depending on the boundary condition in order to emphasize the differences in curves shape. The curves obtained for cells filled with the tyre-sand mixture are not presented because they were similar in shape to the curves obtained with sand cells.

The conclusions that can be drawn from these results concern the fill materials and the lateral boundary conditions. The fill material showed the following trends:

- The curves of the impact force on fine material cells were rather smooth, whereas those obtained for stone cells showed rapid force variations over the whole impact duration. The average amplitude of the force drops after $10 \mathrm{~ms}$ in $\mathrm{MC}$ and FD conditions was of $30 \mathrm{kN}$;

- In FD conditions the impact force curves exhibited a pronounced peak at the beginning of the impact, either followed by a quasi plateau (stone cell) or a progressive force increase until a second peak was reached at a higher force value (fine material cells) (Fig. 6);

- The second peak on the impact force curve for sand cells in FD conditions, at about $42 \mathrm{~ms}$, was immediately followed by the maximum of the transmitted force (Fig. 6);

- Impacts on stone cells lasted longer, transmitted a lower force and led to a higher cell penetration, whatever the boundary conditions. Stones crushing was observed for 

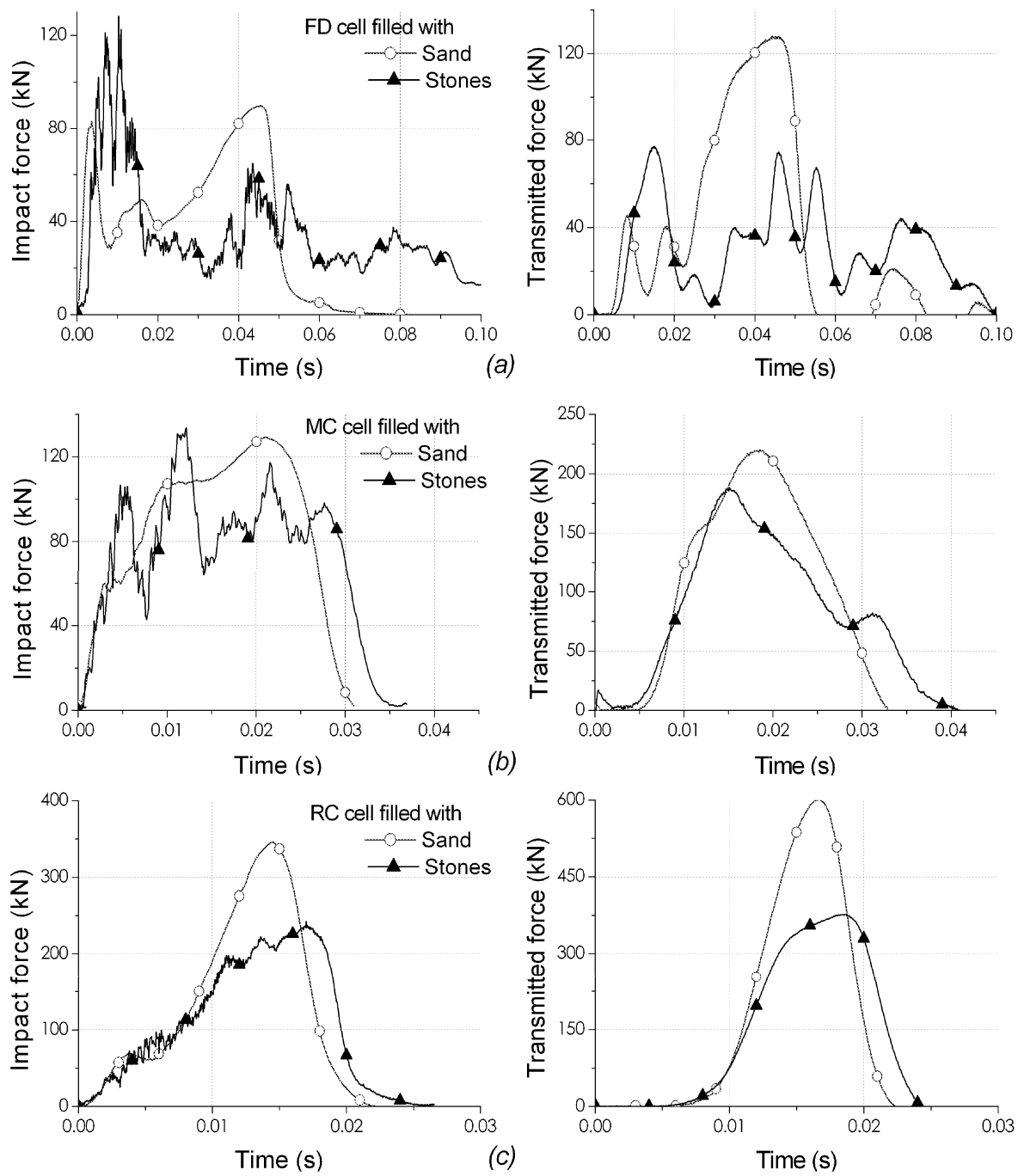

Fig. 6. Response in terms of impact force and transmitted force of geocells filled with stones or sand in different lateral boundary conditions: (a) free to deform - FD; (b) material confinement - MC and (c) rigid confinement - RC.

all the boundary conditions and was generalised in RC conditions;

- Both the impact and transmitted forces were lower with sand cells than with mixture cells for all the boundary conditions (Table 1, Fig. 7);

More specifically, for the boundary conditions:

- After $10 \mathrm{~ms}$, the cell responses in terms of impact force were very different depending on the boundary conditions, while the curves were very similar before $5 \mathrm{~ms}$ (Fig. 8);

- Restraining the lateral deformation (from FD to RC conditions) led to (i) the reduction of both the penetration and the impact duration by a factor of 3 to 4 (Table 1), (ii) the increase in both the maximum values of the impact and the transmitted force. Impact force on sand cells appeared to be more sensitive to the boundary conditions than on stone cells. The increase ratio from FD to $\mathrm{RC}$ conditions was of 3.8 in the case of sand cells vs. 1.7 for stone cells. In contrast, the maximum transmitted force increase was similar for both fill materials, with a ratio of about 5 (Table 1);

- Restraining the lateral deformation (from FD to RC conditions) increased the coefficient of restitution. In fact, the boulder rose again or rebounded with cells filled with sand or tyre-sand mixtures and also after impacts on stone cells in RC conditions (Table 1);

- The maximum force transmitted by the cells in FD conditions was the lowest, followed by the cells in MC conditions (Fig. 7); 


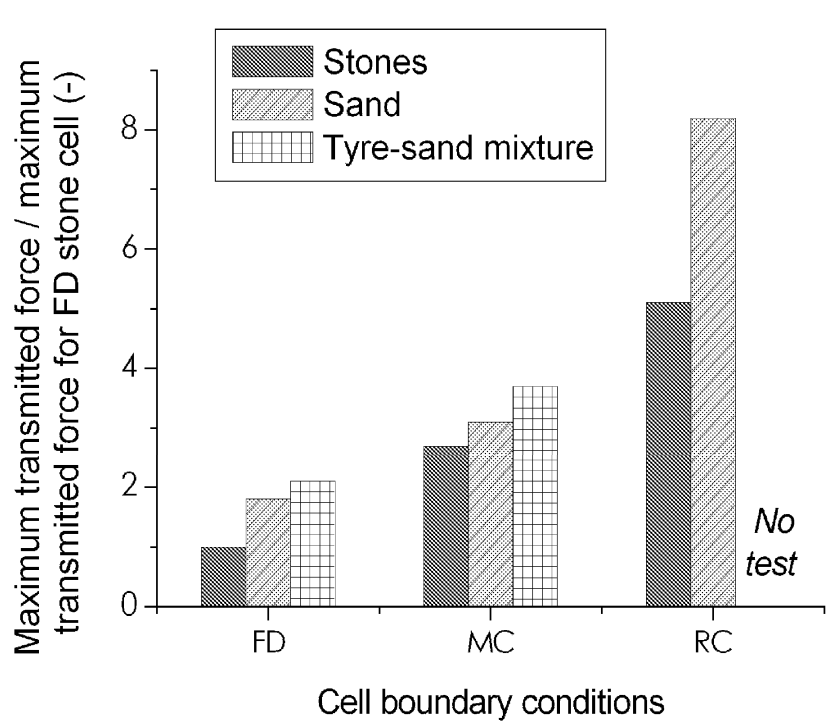

Fig. 7. Maximum transmitted force in the different conditions. Relative value considering the stone cell in FD conditions as the reference.

In addition, except in the case of stone cells in the FD conditions, the maximum transmitted force was higher than the maximum impact force, with a maximum ratio of 2 .

These results clearly show that both the boundary conditions and the fill material have a great influence on the cell response. As presented in Fig. 7, the transmitted force depends essentially on the boundary conditions and less on the fill material.

\section{Discussion}

From the beginning of the impact, the kinetic energy of the impacting boulder is progressively transferred to the cell under the form of kinetic energy and strain energy (Masuya and Kajikawa, 1991). After transit through the cell, the energy is transferred to the rigid base as strain energy. However, depending on both the lateral boundary conditions and the fill materials, the response of the cell to this energy transfer will be different. The impact force curves illustrate this difference in response.

In an impact on a stone cell, the rapid variations observed on the impact force curves is explained by the coarse nature of the fill material. The cell contains a limited number of "particles" (about 100). In such a granular media, the forces transit through force chains (Radjai et al., 1998), involving only a fraction of the particles and forming column patterns. Any particle movement or crushing in these columns causes a sudden drop in the impact force (Tsoungui et al., 1999). For laterally free-to-deform cells, both energy transfers are possible. Stones are crushed and progressively move outwards (second picture on Fig. 9). The cell expands laterally, giving rise to partial fluidisation by reducing the number of contacts between stones (Bourrier et al., 2008), explaining the force drop and plateau. By contrast, if the stone cell is rigidly confined, the stones displacement is strongly restricted and the kinetic energy of the boulder is mainly transferred as strain energy, leading to a high number of crushed stones when in excess. Thus, the boundary conditions govern how energy is transferred through the cell.

For the same reasons, the ratio of kinetic vs. strain energy transferring through the cells filled with fine materials is also governed by the boundary conditions. However, the main difference is that the transfer of energy through the particle assembly causes it to compact (Scott and Pearce, 1975). This stands out from impacts on rigidly confined cells where the slope of the impact force curve increases up to the peak (Fig. 6c). With the laterally free-to-deform cells, the second peak, observed at about $42 \mathrm{~ms}$, is also caused by the fill material compaction. In this situation, compaction results from the confining effect by the envelope: when deformed, the envelope applies a confining stress on the fill material (Bathurst and Rajagopal, 1993). This confinement effect is delayed because of (i) the initial cubic shape of the cell and (ii) the hexagonal shape of the metallic mesh (Lambert, 2007). High-speed digital camera films showed that in this situation the boulder rebound after impact was accompanied by an elastic stress release of the envelop, explaining the rebound (Fig. 10).

Thus the prevailing phenomena occurring in the cell and leading to energy transfer are actually different from one situation to another.

Moreover, the above-mentioned comments indicate that the response of a laterally free-to-deform cell in terms of impact force reveals its composite nature. The cell is composed of two elements: the fill material and the envelope. The cell dynamic response depends on the characteristics of both. On the other hand, the confining effect by the envelope does not play an important role in the case of confined cells (MC and $\mathrm{RC}$ conditions) since it requires a large lateral deformation of the cell which is not attained (Lambert, 2007).

Crushing is a fundamental phenomenon in the response of stone cells. Stone crushing has two consequences. First, it dissipates energy which is not quantified here. Second, it limits the impact force to a threshold value which is proportional to the crushing resistance of the stones (Lambert, 2007) and to the contact area between the impacting boulder and the cell. Indeed, the impact force equals the sum of the forces transitting through the force chains in the cell. The higher the crushing resistance of the stones, the higher the force transitting through each chain and the larger the contact area, the higher the number of force chains involved. The impact force drops observed on stone cells in MC and FD conditions can be associated with stones crushing. This phenomenon also explains that in RC conditions the slope of the impact force tends to diminish about $10 \mathrm{~ms}$ after contact whereas it increases progressively up to the peak in the 

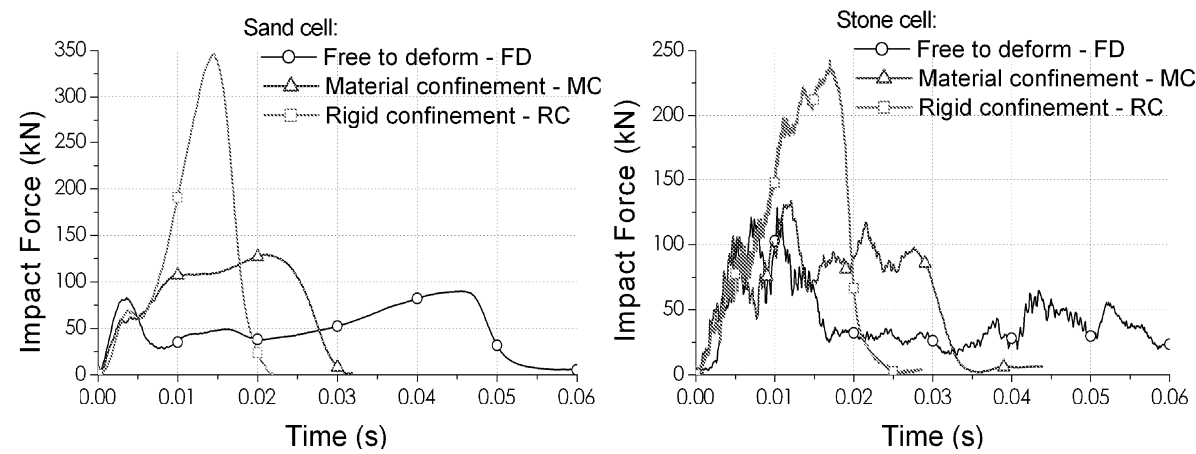

Fig. 8. Influence of the cell lateral boundary conditions on the impact force on cells filled with sand (left) and stones (right).

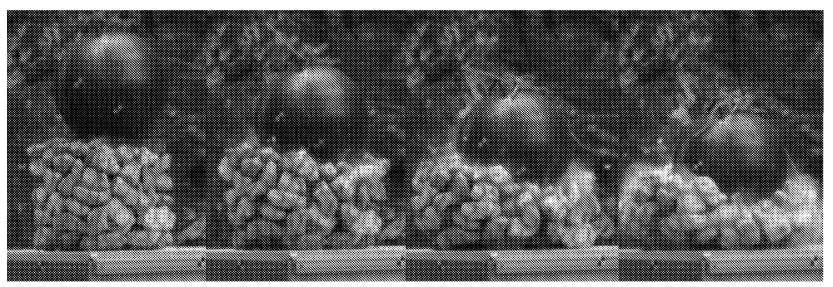

Fig. 9. Impact on a cell filled with stones and laterally free to deform (FD) at $t=0,20,40$ and $80 \mathrm{~ms}$.

case of a sand cell. The impact force limitation is clearly illustrated in MC conditions, with fluctuations around $100 \mathrm{kN}$ between 0.01 and $0.03 \mathrm{~s}$ (Fig. 6b). This impact force limitation results in a greater penetration of the boulder and a longer-lasting impact. By comparison a fine fill material progressively compacts with increasing boulder penetration leading to the increase in the impact force. The influence of sand compaction appears clearly whatever the boundary conditions: the maximum impact force is always reached a few milliseconds before the end of the impact, thus for the highest penetration. It is immediately followed by the maximum transmitted force.

The impact force curves thus appear to be highly relevant in understanding the behaviour of the impacted cells and in interpreting the transmitted force curves. They also reveal the dynamics of the energy transfer from the boulder to the cell. Nevertheless, these data are of limited value considering this study's goal of determining the conditions for a lower transmitted force. It is worth noting that the transmitted force is most often higher than the impact force. Moreover, the ratio between the two depends on the impacted structure. Various authors (Masuya and Kajikawa, 1991; Montani Stoffel, 1998; Calvetti, 1998; Calvetti et al., 2005) have observed this phenomenon, referred to as dynamic amplification by Calvetti et al. (2005). The ratio ranged from 1.1 to 3 . The consequence is that the impact force alone is definitely not sufficient to estimate the transmitted force.

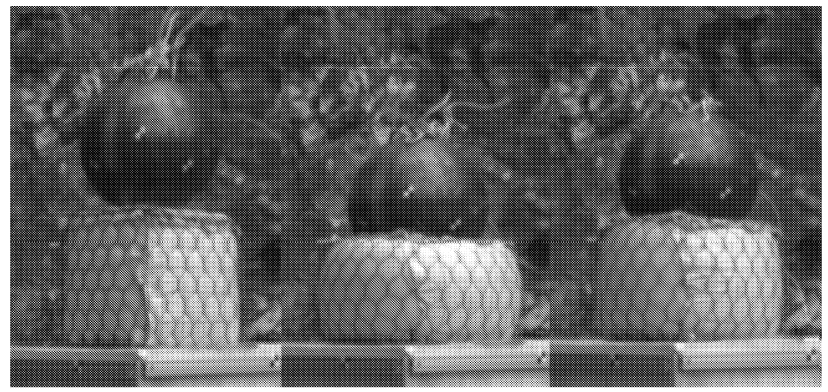

(a)

(b)

(c)

Fig. 10. Impact on a cell filled with sand and laterally free to deform (FD) at the beginning of the impact (a), maximal penetration (b) and during the rebound (c).

Figure 7 clearly shows that the optimal configuration for the reduction of the transmitted force consists of a laterally free-to-deform cell filled with stones. In this situation, the cell is highly deformable and the force opposed by the cell to the boulder penetration is limited. Moreover, the fill material dissipates energy, mainly by friction and crushing. The tyresand mixture is less effective than sand alone as fill material for all the boundary conditions. Considering the differences in the characteristics of these materials (unit weight, peak strength, etc.) different behaviours were expected. However, the complexity of the phenomena involved in the impact make it impossible to explain the trend observed. In fact, the tyre-sand ratio of this mixture was defined based on static tests (Gotteland et al., 2005) and this criterion appears not to be satisfactory for dynamical loadings.

The boundary conditions have a greater influence on the transmitted force than the type of fill material. Thus, optimising the boundary conditions seems to be a valuable alternative to reduce the transmitted force.

Of course, other phenomena take place at the structure scale, involving a set of cells, which cannot be investigated from a single cell laid on a rigid base. For instance, diffusion 
of forces within the structure is not considered. Obviously, a laterally free-to-deform cell directly subjected to impact does not diffuse the forces in the structure, contrary to a cell in lateral contact with other cells. In this context, it is more appropriate to consider stresses rather than forces. In the case of soils, it is generally assumed that the stress diffuses within a cone in the material (Calvetti, 1998; Montani Stoffel, 1998; Nomura et al., 2002). Montani Stoffel (1998) observed that the diffusion angle for three cushion layers vary significantly, ranging from 33 to $47^{\circ}$, and that the distribution of stress beneath the soil layer is not uniform. In a cell filled with different types of material and confined by other cells, the diffusion problem is more complex. First, the envelope's influence should not be neglected because it may modify the diffusion mechanisms. Second, the few available data concerning both the diffusion angle and the stress distribution in soil are not suitable for impacts on stone layers or on tyre-sand mixture layers. Considering the differences between the fill materials investigated here, one can postulate that taking into account diffusion will lead to different conclusions than those drawn from the force-based criterion. Moreover, the rigid base is not really representative of the boundary conditions at the rear of the cell at the structure scale. The impacted cell is expected to move inwards of the structure, depending on the characteristics of this backing and giving opportunity for other phenomena to take place. One can expect a reduction of the impact force and an increase of both the impact duration and the boulder penetration. These two points are being addressed within the framework of the REMPARe project.

\section{Conclusions}

To investigate the behaviour of geocells as components of rockfall protection embankments, a series of impact tests using a $260 \mathrm{~kg}$ spherical boulder were performed.

The response of the geocell was evaluated in terms of the impact force and the force transmitted by the geocell to its base. The effectiveness was evaluated in terms of the minimisation of the transmitted force. Based on this criterion, the optimum consists of a geocell filled with a coarse granular material that is laterally free to deform. The coarse granular fill material geocell appears to be the most effective whatever the geocell boundary conditions, because of particle crushing. Laterally free-to-deform geocells transmit the lowest force. Nevertheless, the transmitted force-based criterion is not sufficient to evaluate the ability of a geocell to reduce the effort transmitted in the impacted embankment because it does not account for diffusion. New developments are necessary to account for diffusion in the fill material.

In addition, these experiments provide a large data base that can be used for developing numerical models. For instance, a numerical model based on a discrete element method was developed to describe gabion geocells (Bertrand et al., 2006) and simulate the response of a structure composed of an assembly of geocells (Nicot et al., 2007). The relevance of such numerical models requires calibration and validation procedures from experimental data.

Acknowledgements. The REMPARe project is supported by the French National Research Agency (ANR). The authors are grateful to the research consortium VOR-RNVO and the PGRN (Natural Hazard Pole of Grenoble) from the Isère General Council for their financial support, and to France Macaferri for providing the gabion cages. P. Perrotin (LOCIE-ESIGEC, Université de Savoie) is also thanked for managing of the experimental site (Grésy-sur-Aix) and for the high-speed camera images.

Edited by: A. Volkwein

Reviewed by: S. Dash and H. Masuya

\section{References}

Agostini, R., Cesario, L., Conte, A., Masetti, M., and Papetti, A.: Flexible gabion structures in earth retaining works, Tech. rep., Maccaferri, Bologna Italy, 1987.

Bathurst, R. and Rajagopal, K.: Large-scale triaxial compression testing of geocell-reinforced granular soils, Geotech. Test. J., 16, 296-303, 1993.

Bertrand, D., Nicot, F., Gotteland, P., and Lambert, S.: Modelling a geo-composite cell using discrete analysis, Comput. Geotech., 32, 564-577, 2006.

Blovsky, S.: Model tests on protective barriers against rockfall, in: 15th EYGEC - European Young Geotechnical Engineers Conference, Dublin, Ireland, 11-14 september 2002.

Bourrier, F., Nicot, F., and Darve, F.: Physical processes within a 2D granular layer during an impact, Granular Matter, 10, 415-437, 2008.

Burroughs, D., Henson, H. H., and Jiang, S. S.: Full scale geotextile rock barrier wall testing, analysis and prediction, in: Geosynthetics' 93, Vancouver, Canada, 30 march-1 april, 959-970, 1993.

Calvetti, F.: Distinct element evaluation of the rock-fall design load for shelters, Rivista Italiana di Geotecnica, 32, 63-83, 1998.

Calvetti, F., Di Prisco, C., and Vecchiotti, M.: Experimental and numerical study of rock-fall impacts on granular soils, Rivista Italiana di Geotecnica, 4, 95-109, 2005.

Carotti, A., Di Prisco, C., Vecchiotti, M., Recalcati, P., and Rimoldi, P.: Modeling of geogrid reinforced embankments for rockfall protection, in: 3rd European Geosynthetics Conference, Munich, Germany, 1-3 march, 675-680, 2004.

Chen, R. and Chiu, Y.: Model tests of geocell retaining structures, Geotext. Geomembranes, 26, 56-70, 2008.

Chikatamarla, R.: Optimisation of cushion materials for rockfall protection galleries, $\mathrm{PhD}$ thesis, Swiss federal institute of technology, Zurich, 2005.

Dash, S. K., Rajagopal, K., and Krishnaswamy, N.: Behaviour of geo-cell-reinforced sand beds under strip loading, Can. Geotech. J., 44, 905-916, 2007.

Descoeudres, F.: Aspects géomécaniques des instabilités de falaises rocheuses et des chutes de blocs, Publications de la société suisse de mécanique des sols et des roches, 135, 3-11, 1997. 
Gotteland, P., Lambert, S., and Balachowski, L.: Strength characteristics of tyre chips-sand mixtures, Studia Geotechnica et Mechanica, 27, 55-66, 2005.

Gourvès, R., Reiffsteck, P., and Vignon, J.: Study of confinement effect in geocells, in: Eurogeo 1 - Geosynthetics:Applications, design and construction, Maastricht, The Netherlands, 30 september-2 october, 455-458, 1996.

Hearn, G., Barrett, R. K., and Henson, H. H.: Development of effective rockfall barriers, J. Transp. Eng., 121, 507-516, 1995.

Iizuka, A., Kawai, K., Kim, E. R., and Hirata, M.: Modeling of the confining effect due to the geosynthetic wrapping of compacted soil specimens, Geotext. Geomembranes, 22, 329-358, 2004.

Jaecklin, F.: Innovative design for repairing Gondo mudslide by $20 \mathrm{~m}$ high geogrid wall, in: 8th international conference on geosynthetics, Ozaka, Japan, 18-22 September, 1223-1228, 2006.

Labiouse, V., Descoeudres, F., Montani, S., and Schmidtaler, C.A.: Etude expérimentale de la chute de blocs rocheux sur une dalle en béton armée recouverte par des matériaux amortissants, Revue française de Géotechnique, 69, 41-62, 1994.

Lambert, S.: Mechanical behaviour of geocells with application to cellular rock-fall protection dykes components, $\mathrm{PhD}$ thesis, Joseph Fourier, Grenoble, 2007 (in French).

Lepert, P. and Corté, J.-F.: Etude en centrifugeuse de l'impact de gros blocs rocheux sur un remblai de protection, in: Centrifuge 88, Paris, France, 25-27 April, 457-465, 1988.

Lorentz, J., Donzé, F., Perrotin, P., and Plotto, P.: Experimental study of the dissipative efficiency of multylayered protective structure against rockfall impact, European Journal of Environmental and Civil Engineering, 10, 295-308, 2006.

Madhavi Latha, G., Rajagopal, K., and Krishnaswamy, N.: Experimental and theoretical investigations on geocell-supported embankments, International Journal of Geomechanics, 6, 30-35, 2006.

Masuya, H. and Kajikawa, Y.: Numerical analysis of the collision between a falling rock and a cushion by distinct element method, Computer Methods and Advances in Geomechanics, Beer, Booker, and Carter, Balkema, Rotterdam, The Netherlands, 493-498, 1991.

Montani Stoffel, S.: Sollicitation dynamique de la couverture des galeries de protection lors de chutes de blocs, Ph.D. thesis, EPFL, Lausanne, 1998 (in French).

Nicot, F., Gotteland, P., Bertrand, D., and Lambert, S.: Multi-scale approach to geo-composite cellular structures subjected to impact, International Journal for Numerical and Analytical Methods in Geomechanics, 31, 1477-1515, 2007.

Nomura, T., Inoue, S., Fuchigami, M., Yokota, Y., Kubo, T., Tatta, N., and Arai, K.: Experimental research of reinforced soil wall for rock-fall protection, in: 7th International conference on geosynthetics, Nice, France, 22-27 september, 303-308 2002.

Peila, D., Castiglia, C., Oggeri, C., Guasti, G., Recalcati, P., and Rimoldi, P.: Testing and modelling geogrid reinforced soil embankments subject to high energy rock impacts, in: 7th International conference on geosynthetics, Nice, France, 22-27 september, 133-136, 2002

Peila, D., Oggeri, C., and Castiglia, C.: Ground reinforced embankments for rockfall protection: design and evaluation of full scale tests, Landslides, 4, 255-265, 2007.
Pichler, B., Hellmich, C., Eberhardsteiner, J., and Mang, H.: Assesment of protection systems for buried steel pipelines endangered by rockfall, Comput.-Aided Civ. Inf., 20, 331-342, 2005.

Plassiard, J.-P., Donzé, F., and Plotto, P.: High energy impact on embankments - a numerical discrete approach, in: NUMOG XIV, Ottawa, Canada, 25-27 August, 609-614, 2004.

Racana, N., Gourves, R., and Grediac, M.: Experimental study of the mechanical behaviour of soils reinforced by geocells, in: 7th International conference on geosynthetics, Nice, France, 22-27 september, 1349-1351, 2002

Radjai, F., Wolf, D. E., Jean, M., and Moreau, J.-J.: Bimodal character of stress transmission in granular packings, Phys. Rev. Lett., 80, 61-64, 1998.

Rajagopal, K., Krishnaswamy, N., and Madhavi Latha, G.: Behaviour of sand confined with single and multiple geocells, Geotext. Geomembranes, 17, 171-184, 1999.

Reiffsteck, P.: Experimental and theoretical study of soil structure reinforced by a three-dimensionnal alveolar geotextile, Revue française de Géotechnique, 82, 49-62, 1998.

RiskYdrogéo: Risques hydro-géologiques en montagne : parades et surveillance - Projet 179 INTERREG III A - 2004-2006, Tech. rep., http://www.risknat.org/projets/riskydrogeo/, 2006.

Schellenberg, K., Volkwein, A. Denk, M., and Vogel, T.: Falling weight tests on rock fall protection galleries with cushion layers, in: Interdisciplinary workshop on rockfall protection, Morschach, Switzerland, 23-25 june, 99-101, 2008.

Scherbatiuk, K., Rattanawangcharoen, N., Pope, D., and Fowler, J.: Generation of a pressure-impulse for a temporary soil wall using an analytical rigid-body rotation model, Int. J. Impact Eng., 35, 530-539, 2008.

Scott, R. and Pearce, R.: Soil compaction by impact, Géotechnique, 25, 19-30, 1975.

Sung, E., Yashima, A., Aminata, D., Sugimori, K., Sawada, K., Inoue, S., and Nishida, Y.: Numerical assessment of the performance of protecting wall against rockfall, in: 5th International Symposium on Earth Reinforcement, Kyushu, Japan, 1416 november, 861-867, 2007.

Tissières, P.: Ditches and reinforced ditches against falling rocks, in: Joint Japan-Swiss scientific seminar on impact load by rock falls and design of protection structures, Kanazawa, Japan, 4-7 October, 65-68, 1999.

Tsoungui, O., Vallet, D., and Charmet, J.-C.: Numerical model of crushing of grains inside two-dimensional granular materials, Powder Technol., 105, 190-198, 1999.

Wesseloo, J., Visser, A., and Rust, E.: The stress-strain behaviour of multiple cell geocell pack, Geotext. Geomembranes, 27, 31-38, 2009.

Yoshida, H.: Recent experimental studies on rockfall control in Japan, in: Joint Japan-Swiss scientific seminar on impact by rock falls and design or protection strcutures, Kanazawa, Japan, 4-7 October, 69-78, 1999.

Yuu, J., Han, J., Rosen, A., Parsons, R., and Leshchinsky, D.: Technical review of geo-cell-reinforced base courses over weak subgrade, in: First Pan American geosynthetics conference, Cancun, Mexico, 2-5 march, 1022-1030, 2008.

Zornberg, J., Cabral, A., and Viratjandra, C.: Behaviour of tire shred-sand mixtures, Can. Geotech. J., 41, 227-241, 2004. 